\author{
Asian Journal of \\ Medical and Biological Research \\ ISSN 2411-4472 (Print) 2412-5571 (Online) \\ www.ebupress.com/journal/ajmbr
}

\title{
Article \\ Effect of nutrients enriched feed premix on the growth performance of major carps Rohu, Catla and Mrigal in a polyculture system
}

\author{
Md. Faridur Rahman ${ }^{1}$, Shamima Sultana ${ }^{2}$, Manash Kabiraj ${ }^{1}$ and Md. Alimullah ${ }^{1}$ \\ ${ }^{1}$ Fisheries and Marine Resource Technology Discipline, Khulna University, Khulna - 9208, Bangladesh \\ ${ }^{2}$ Assistant Professor, Fisheries and Marine Resource Technology Discipline, Khulna University, Khulna - 9208, \\ Bangladesh \\ *Corresponding author: Shamima Sultana, Assistant Professor, Fisheries and Marine Resource Technology \\ Discipline, Khulna University, Khulna-9208, Bangladesh. Phone: +8801737167118; E-mail: \\ shamimasultana87@gmail.com
}

Received: 07 September 2018/Accepted: 24 September 2018/ Published: 30 September 2018

\begin{abstract}
To evaluate the effect of nutrients enriched feed premix on the growth performance of major carps Rohu (Labeo rohita), Catla (Catla catla) and Mrigal (Cirrhinus mrigala) in a polyculture system, the present experiment was carried out in six earthen ponds located at Khulna University of Bangladesh for a period of 90 days. Two treatments each with three replications were stocked with $40 \%$ Rohu, 30\% Catla and 30\% Mrigal with a total stocking density of 10000/ha. T-2 was treated with feed premix at the rate of $4 \mathrm{~g} / 1 \mathrm{~kg}$ feed while T-1 was not treated with any feed premix. Both treatments were applied normal feed twice a day at the rate of $2 \%$ to $4 \%$ of the body weight of the fingerlings. The net fish production was found to be $2238.06 \mathrm{~kg} / \mathrm{ha}$ and 3607.33 $\mathrm{kg} / \mathrm{ha}$ in T-1 and T-2 respectively. The results showed that fish production was significantly higher in T-2 than $\mathrm{T}-1(\mathrm{P}<0.05)$. T-2 showed 0.60 times greater fish production than that of $\mathrm{T}-1$.
\end{abstract}

Keywords: feed premix; growth; polyculture; production; carp

\section{Introduction}

Aquaculture is the fastest-growing food-producing sector in the world with an annual rising rate of 8.9-9.1\% since the 1970s. According to FAO (2016), global aquaculture has grown dramatically over the past 50 years to around 52.5 million tons and accounting for around 50 percent of the world's fish food supply. Out of all, Asia dominates aquaculture production of the world and contributes around $87 \%$ to the global cultured fin-fish production of 25.7 million tons in 2005 (De Silva et al., 2006). Bangladesh has achieved $5^{\text {th }}$ position in aquaculture production (FAO 2017). Bangladesh is a small dense populated country where day by day protein requirement is rising due to population inflation. As a developing country fishes are the major sources of animal protein to most rural Bangladeshi's (DoF, 2012; Hossain et al., 2002 and Amin et al., 2009). In our country aquaculture is mostly represented by pond culture. Carp polyculture is an age-old popular method in southasia, specifically in Bangladesh and India, where it is the major aquaculture production system (Miah et al., 1997; FAO, 1997; Reddy et al., 2002). In south Asian, a wide variety of fish species are cultured. Among various species Labeo rohita (Hamilton), Catla catla (Hamilton) and Cirrhinus mrigala (Hamilton) are very popular (Uddin et al., 1994; FAO, 1997; Miah et al., 1997; Kanak et al., 1999) in polyculture system. In Bangladesh, aquaculture habitually has been drowned polyculture of three Indian major carps including Catla catla, Labeo rohita and Cirrhinus mrigala (Azim and Wahab, 2003). The widespread use of polyculture farming practices is increasing dietary nutrition, productivity and profitability of farming households in rural Bangladesh. In polyculture system one species enhance the food accessibility for other species and as a result promote the entire fish yield. The growth performance of Indian major carps viz; Labeo rohita, Catla catla and Cirrhinus mrigala can be developed by providing available enough amount of innate food and balanced artificial diet. As we know 
that vitamins, minerals, prebiotics and so on are a prerequisite for normal cell function, various biochemical and physiological processes, development and boost up immunity of farmed fish (Panush and Delafuente, 1985; National Research Council, 1993; Hamre, 2011; National Research Council, 2011; Halver, 2002; Dhur, Galan and Hercberg 1991; West et al., 1991; Jurin and Tannock 1972; West et al., 1991; BASF, 2000 and Chakraborty et al., 1976). Considering above facts, attempts were taken to investigate the effect of nutrients enriched feed premix on the growth promotion of Rohu, Catla and Mrigal in a polyculture system.

\section{Materials and Methods}

\subsection{Study area and period}

The study was conducted in the experimental pond complex II of Fisheries and Marine Resource Technology discipline, Khulna University, Khulna, Bangladesh during February to May, 2018. All experimental ponds were same sizes and rectangular in shape with a maximum depth of $1.5 \mathrm{~m}$. Additionally, all the ponds were fully exposed to prevailing sunlight.

\subsection{Experimental Design}

The trial was conducted into two different treatments with three replications each (Table 1).

\subsection{Prestocking management}

Ponds were renovated and cleaned of aquatic vegetation in January. All unwanted fishes and other aquatic organisms were eradicated by applying rotenone and repeated netting. Pond dikes were repaired using the excavated bottom soils. The weeds of embankment were also cleaned manually. Agricultural lime $\left(\mathrm{CaCO}_{3}\right)$ was applied to the pond bottom at the rate of at a rate of $1 \mathrm{~kg} / \mathrm{decimal}$. The ponds were filled with water after seven days of liming from adjacent deep tube well by using pump. After three days, all ponds were fertilized with inorganic fertilizer like, Urea, TSP, and Molasses-yeast mixture at the same rate. After the first fertilization and before fish stocking, the ponds were left 10 days to allow plankton development.

\subsection{Stocking}

Rohu, Catla and Mrigal were collected from a local nursery named Sowakat Ali at Dumuria Upazilla of Khulna District. The ponds were stocked with fish after ten days of fertilization. All fish were released in the ponds in early morning after acclimatization.

\subsection{Post stocking management}

All ponds were subject to the same regime of feed application. In case of treatment, firstly, fish feed was mixed with feed premix (Table 2) by using soybean oil. After that, fish were fed with that additives mixed feed in treatment (T2). Fish were fed at the rate of $2 \%$ of total body weight of stocking fingerlings twice daily at 8:30 am and 4:30 pm. Additionally, feeding rate was increased gradually from $2 \%$ to $4 \%$ of total body weight of the fish. However, no feed premix was applied in control (T-1) (Table 1). Furthermore, all ponds were fertilized with inorganic fertilizer like, Urea, TSP, and Molasses-yeast mixture at the same rate fortnightly.

\subsection{Water sampling and analysis}

Water quality parameters such as temperature, $\mathrm{pH}$, dissolved oxygen level (DO), salinity, alkalinity and hardness were monitored in every 30 days' interval to ensure suitable culture condition. Samples were brought to the Water Quality Research Laboratory, FMRT Discipline, Khulna University, Khulna for chemical analysis.

\subsection{Growth parameters}

Fish sampling were conducted at monthly intervals to assess their growth and health status. The following equation were used to evaluate the growth and survival rate of fishes:

Weight gain $(\mathrm{cm})=$ Average final weight $(\mathrm{g})$ - average initial weight $(\mathrm{g})$

Survival rate $(\%)=($ No. of fish harvested/ Initial no. of fishes) $\times 100$

\subsection{Harvesting of Fish}

After 90 days of rearing, the fish were harvested from all the ponds. Final harvesting was done by dewatering the ponds with a submerged low fit pump. During harvest, all fishes were counted and weighted from each pond to assess the survival rate and production. 
2.9. Statistical Analysis

The data collected during experiment were recorded. Data were analyzed using MS excel and the statistical package SPSS (16). One-way ANOVA was performed to observe the degree of difference between the treatments at the $5 \%$ level of significance.

\section{Results}

\subsection{Water quality parameter}

All the water quality parameters were present within acceptable range. The overall mean values of each water quality parameter in different treatments are presented in Table 3.

Temperature, salinity, $\mathrm{pH}$, dissolved oxygen, alkalinity and hardness were varied from 22 to $27{ }^{\circ} \mathrm{C}, 3$ to $4 \mathrm{ppt}$, 7.3 to $7.8,5$ to $6 \mathrm{mg} / \mathrm{L}, 200$ to $250 \mathrm{mg} / \mathrm{L}, 550-750 \mathrm{mg} / \mathrm{L}$ with mean values of $24.75 \pm 1.75$ and $24.75 \pm 1.98{ }^{\circ} \mathrm{C}$, $3.62 \pm 0.51$ and $3.62 \pm 0.51 \mathrm{ppt}, 7.58 \pm 0.21$ and $7.61 \pm 0.18,5.75 \pm 0.46$ and $5.75 \pm 0.46 \mathrm{mg} / \mathrm{l}, 228.12 \pm 24.77$ and $231.25 \pm 25.87 \mathrm{mg} / \mathrm{l}, 675 \pm 103.50$ and $668.75 \pm 99.77 \mathrm{mg} / \mathrm{l}$ in $\mathrm{T}-1$ and $\mathrm{T}-2$ respectively (Figure 1-6). No parameters were found to be varied $(\mathrm{p}>0.5)$ between two treatments.

Table 1. Layout of the experiment.

\begin{tabular}{lll}
\hline Parameter/Stocking Density & Treatment $(T-1)$ & Treatment (T-2) \\
\hline Area of each pond $\left(\mathrm{m}^{2}\right)$ & 120 & 120 \\
Water depth $(\mathrm{m})$ & $1-1.5$ & $1-1.5$ \\
Rohu (ind. $\left./ \mathrm{m}^{2}\right)$ & 0.4 & 0.4 \\
Catla (ind. $\left./ \mathrm{m}^{2}\right)$ & 0.3 & 0.3 \\
Mrigal (ind. $\left./ \mathrm{m}^{2}\right)$ & 0.3 & 0.3 \\
Feed premix & Not Applied & Applied at rate of $4 \mathrm{~g} / 1 \mathrm{~kg}$ feed \\
Composition of feed premix & Not Applied & Vitamins, Minerals, Amino acids, Prebiotic \\
Replication & 3 & 3 \\
\hline
\end{tabular}

Table 2. Composition of feed premix.

\begin{tabular}{lll}
\hline Type & Name & Content \\
\hline & Vitamin A & $14,000,000 \mathrm{I} . U$. \\
& Vitamin $\mathrm{D}_{3}$ & $3,000,00 \mathrm{I.U}$. \\
Vitamins & Vitamin E & $3,500 \mathrm{mg}$ \\
& Vitamin C & $5,000 \mathrm{mg}$ \\
& Vitamin $\mathrm{B}_{1}$ & $1,000 \mathrm{mg}$ \\
& Vitamin $\mathrm{B}_{2}$ & $700 \mathrm{mg}$ \\
& Vitamin $\mathrm{B}_{6}$ & $500 \mathrm{mg}$ \\
& Vitamin $\mathrm{B}_{12}$ & $1,800 \mathrm{mcg}$ \\
& Iron $(\mathrm{Fe})$ & $700 \mathrm{mg}$ \\
Minerals & Copper (Cu) & $70 \mathrm{mg}$ \\
& Manganese $(\mathrm{Mn})$ & $1,400 \mathrm{mg}$ \\
& Cobalt (Co) & $12 \mathrm{mg}$ \\
& Zinc (Zn) & $2,000 \mathrm{mg}$ \\
& Calcium (Ca) & $2,50,000 \mathrm{mg}$ \\
Amino Acids & Magnesium (Mg) & $5,000 \mathrm{mg}$ \\
& Phosphorous (P) & $1,000 \mathrm{mg}$ \\
Prebiotic & Lysine & $15,000 \mathrm{mg}$ \\
& Methionine & $20,000 \mathrm{mg}$ \\
& Threonine & $1,606 \mathrm{mg}$ \\
& Glycine & $2,500 \mathrm{mg}$ \\
& Tryptophan & $200 \mathrm{mg}$ \\
& Fructo-oligosacharides & $10,000 \mathrm{mg}$ \\
\hline
\end{tabular}


Table 3. Mean $( \pm \mathrm{SD})$ values and ranges of water quality parameters.

\begin{tabular}{lllll}
\hline Parameters & \multicolumn{3}{c}{ T-1 } & T-2 \\
\cline { 2 - 5 } & Mean $( \pm$ SD) & Range & Mean $( \pm$ SD) & Range \\
\hline Temperature $\left({ }^{\circ} \mathrm{C}\right)$ & $24.75 \pm 1.75^{\mathrm{a}}$ & $22-27$ & $24.75 \pm 1.98^{\mathrm{a}}$ & $22-27$ \\
DO $(\mathrm{mg} / \mathrm{l})$ & $5.75 \pm 0.46^{\mathrm{b}}$ & $5-6$ & $5.75 \pm 0.46^{\mathrm{b}}$ & $5-6$ \\
pH & $7.58 \pm 0.21^{\mathrm{c}}$ & $7.3-7.8$ & $7.61 \pm 0.18^{\mathrm{c}}$ & $7.4-7.8$ \\
Alkalinity $(\mathrm{mg} / \mathrm{l})$ & $228.12 \pm 24.77^{\mathrm{d}}$ & $200-250$ & $231.25 \pm 25.87^{\mathrm{d}}$ & $200-250$ \\
Hardness $(\mathrm{mg} / \mathrm{l})$ & $675 \pm 103.50^{\mathrm{e}}$ & $550-750$ & $668.75 \pm 99.77^{\mathrm{e}}$ & $550-750$ \\
Salinity $(\mathrm{ppt})$ & $3.62 \pm 0.51^{\mathrm{f}}$ & $3-4$ & $3.62 \pm 0.51^{\mathrm{f}}$ & $3-4$ \\
\hline
\end{tabular}

*Different superscript letters indicate the significant difference among the treatment $(\mathrm{P}<0.05)$

Table 4. Survival and Production of rohu, catla and mrigal under two treatments.

\begin{tabular}{|c|c|c|c|c|c|c|c|c|c|}
\hline Treatment & & At stocking & & & At harvest & & & $\begin{array}{l}\text { Survival } \\
\text { Rate }(\%)\end{array}$ & $\begin{array}{l}\text { Production } \\
\text { (kg/ha) }\end{array}$ \\
\hline & $\begin{array}{l}\text { Fish } \\
\text { species }\end{array}$ & $\begin{array}{l}\text { Av. Initial wt } \\
\text { (g) }\end{array}$ & $\begin{array}{l}\text { No. of } \\
\text { fish } \\
\text { stocked }\end{array}$ & $\begin{array}{l}\text { Total } \\
\mathrm{wt}(\mathrm{g})\end{array}$ & $\begin{array}{l}\text { Av. Final wt } \\
(\mathrm{g})\end{array}$ & $\begin{array}{l}\text { No of fish } \\
\text { recovered }\end{array}$ & $\begin{array}{l}\text { Total wt } \\
(\mathrm{g})\end{array}$ & $\begin{array}{l}\text { Species } \\
\text { wise }\end{array}$ & Total \\
\hline \multirow[t]{3}{*}{ T-1 } & Rohu & $89.16 \pm 5.78$ & 44 & 3923.04 & $150.12 \pm 9.84^{\mathrm{a}}$ & 39 & 5854.67 & 89 & 2238.06 \\
\hline & Catla & $86.86 \pm 8.12$ & 32 & 2779.52 & $138.77 \pm 7.99^{c}$ & 28 & 3885.56 & 88 & \\
\hline & Mrigal & $74.09 \pm 9.028$ & 34 & 2519.05 & $131.72 \pm 7.05^{\mathrm{e}}$ & 28 & 3688.16 & 84 & \\
\hline \multirow[t]{3}{*}{ T-2 } & Rohu & $89.45 \pm 8.29$ & 44 & 3935.79 & $237.41 \pm 19.02^{\mathrm{b}}$ & 40 & 9496.40 & 90 & 3607.33 \\
\hline & Catla & $85.31 \pm 8.41$ & 32 & 2729.91 & $226.13 \pm 19.65^{\mathrm{d}}$ & 28 & 6331.64 & 88 & \\
\hline & Mrigal & $75.68 \pm 5.97$ & 34 & 2573.12 & $200.59 \pm 17.70^{\mathrm{f}}$ & 29 & 5817.10 & 86 & \\
\hline
\end{tabular}

* Different superscript letters indicate the significant difference among the treatment $(\mathrm{P}<0.05)$

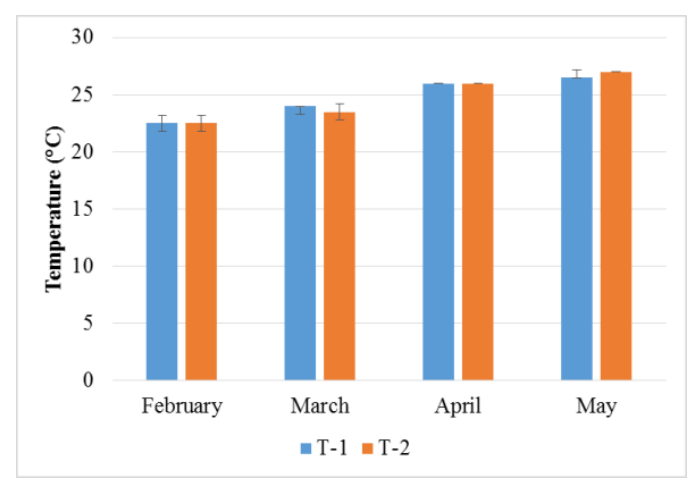

Figure 1. Changing pattern of temperature at two groups in different times.

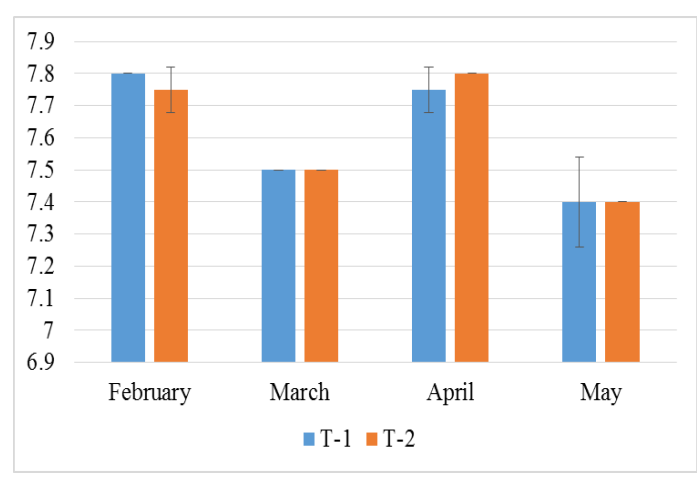

Figure 2. Changing pattern of $\mathrm{pH}$ at two groups in different times. 


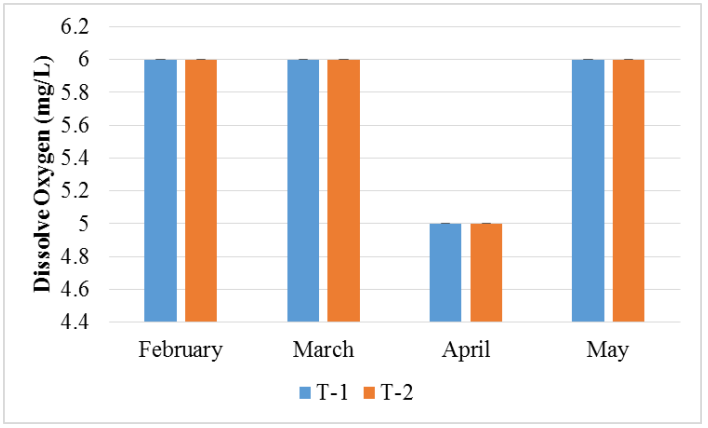

Figure 3. Changing pattern of DO at two groups in different times.

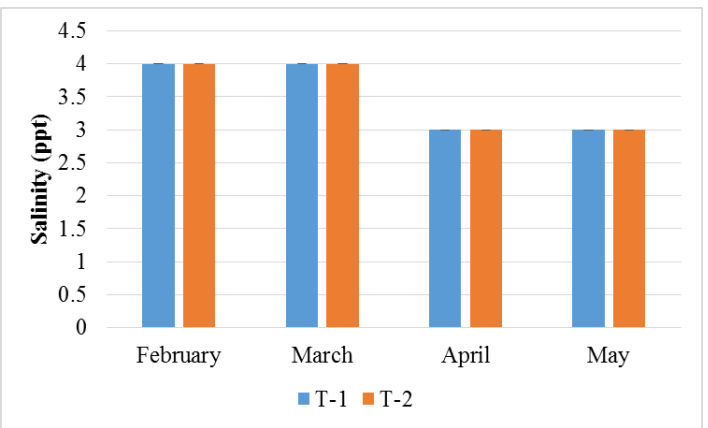

Figure 4. Changing pattern of salinity at two groups in different times.

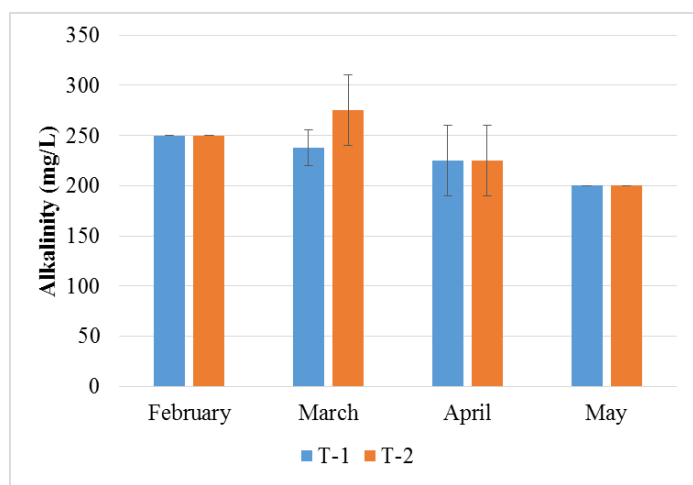

Figure 5. Changing pattern of alkalinity at two groups in different times.

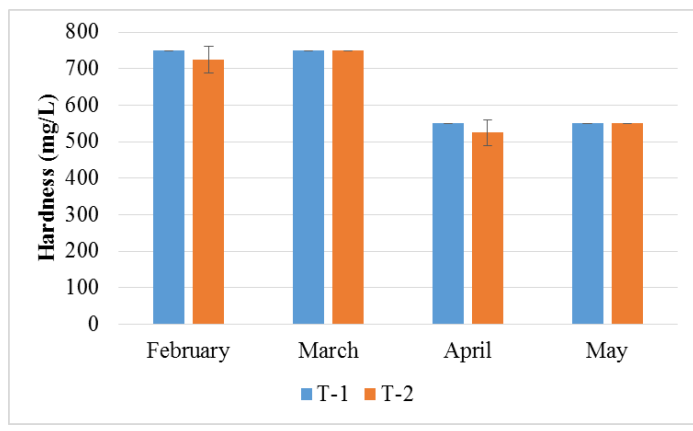

Figure 6. Changing pattern of hardness at two groups in different times. 


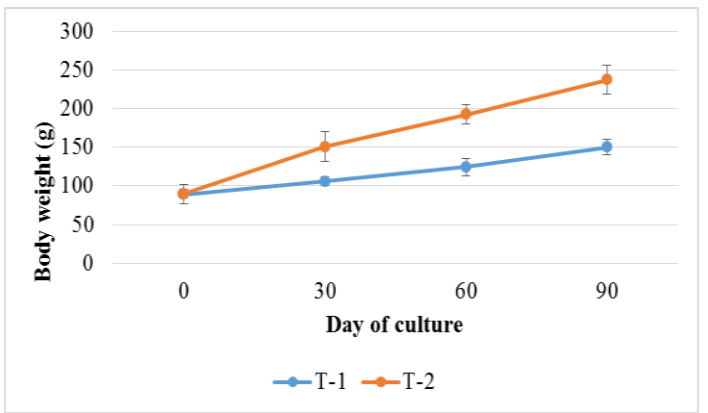

Figure 7. Growth curve of $L$. rohita in two treatments.

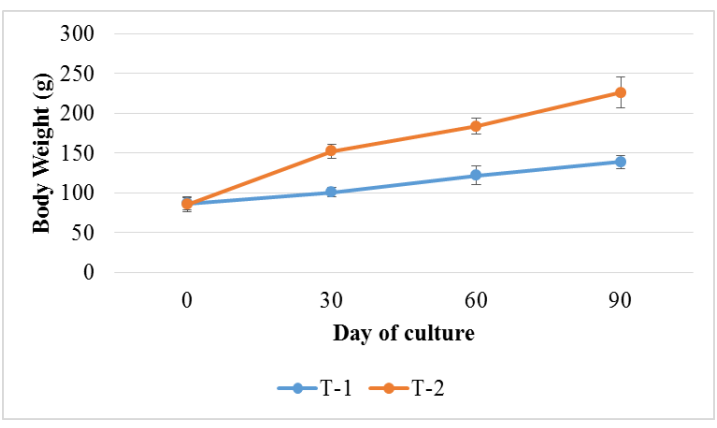

Figure 8. Growth curve of $C$. catla in two treatments.

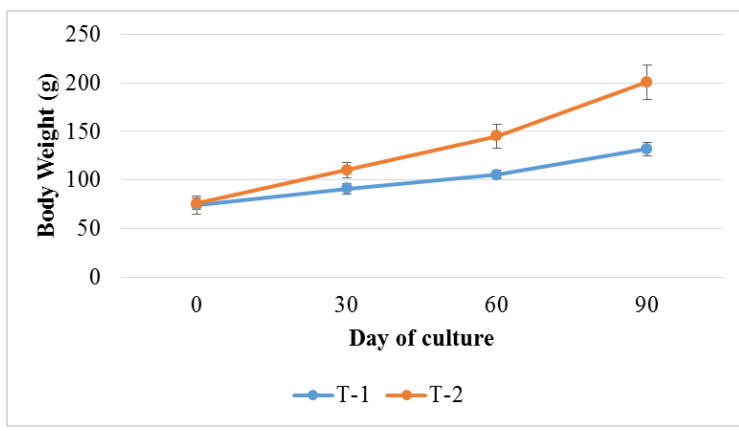

Figure 9. Growth curve of $C$. mrigala in two treatments.

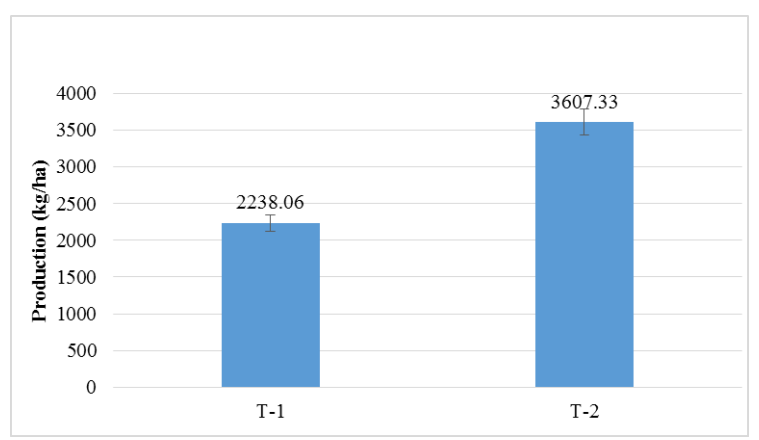

Figure 10. Total production in two treatments.

\subsection{Growth and production}

Details of growth performance and production of fish are presented in Table 4. Among three species, rohu attained the maximum weight at harvest. The weight gain by rohu, catla and mrigal was better in T2, where feed premixes was added. The average final mean individual weights of rohu, catla and mrigal in $\mathrm{T} 1$ and $\mathrm{T} 2$ were $150.13 \pm 9.85 \mathrm{~g}, 138.77 \pm 8.00 \mathrm{~g}, 131.73 \pm 7.05 \mathrm{~g}$ and $237.42 \pm 19.02 \mathrm{~g}, 226.14 \pm 19.65 \mathrm{~g}, 200.59 \pm 17.70 \mathrm{~g}$ respectively. The average final mean individual weights of rohu, catla and mrigal in $\mathrm{T} 1$ and $\mathrm{T} 2$ were significantly different at 
5\% level of significance. The survival rates of rohu, catla, mrigal in T-1 and T-2 were $89,88,84 \%$ and 90,88 , $86 \%$ respectively. Between two treatments, there was no significant difference in the survival rates of rohu, catla and mrigal.

The final production of fish after three months of culture was 2238.06 and $3607.33 \mathrm{~kg} / \mathrm{ha}$ in treatments 1 and 2 respectively. Maximum fish production was obtained in T-2, where growth promoter chemicals was mixed. It was evident from the result that growth of rohu, catla and mrigal in ponds that were treated by feed premix varies (Figure 7-9). Statistical analysis showed that there was significant differences in the production between these treatments. The highest production rate was observed in T-2 having $3607.33 \mathrm{~kg} / \mathrm{ha}$ and the lowest production was found in T-1 having $2238.06 \mathrm{~kg} / \mathrm{ha}$ (Figure 10). Indeed, there was 0.60 times greater net fish production in $\mathrm{T}-2$ than that in $\mathrm{T}-1$.

\section{Discussion}

Water quality is very necessary for the growth of fish. It involves all physical and chemical parameters that may affect the primary production (Zhang, 1987). In the present study, the water quality parameters surveyed in all treatments were found within the acceptable range of fish culture and there was no significant difference among the treatments.

During the experiment the water temperature of treatments was found to vary from $22^{\circ} \mathrm{C}$ to $27^{\circ} \mathrm{C}$, the $\mathrm{pH}$ values of treatments was found to vary from 7.3 to 7.8, the Dissolved Oxygen (DO) of treatments was found to vary from 5 to 6 , the salinity of treatments was found to vary from 3 to $4 \mathrm{ppt}$, the alkalinity of treatments was found to vary from 200 to $250 \mathrm{mg} / \mathrm{L}$, the hardness of treatments was found to vary from 550 to $750 \mathrm{mg} / \mathrm{L}$ in T-1 and T2 respectively which are more or less similar to the finding of Rahman et al. (2006), Huq et al. (2004), Ahamed (2004) and Asaduzzaman (2005) who recorded uniform range during their experiment. There was no significant difference ( $p>0.05)$ among the treatments.

The present study provides experimental evidence on the effect of nutrients enriched feed premix on rohu, catla and mrigal after feeding. Feed premix contains vitamins, minerals, amino acids and prebiotics. Feed introducing feed premix as mentioned earlier showed a clear change of result on growth performance. During the experimental period fish growth rate of rohu, catla and mrigal were measured in every 30 days interval. The growth rate of 2 treatments was showed in (Figure 7, Figure 8, Figure 9) that persuades the growth increment of rohu, catla and mrigal. The yield of this polyculture system is similar to several production levels obtained in other polycultures in the South Asian region, e.g. Shahabuddin et al. (1994) obtained yields of 2000-3400 kg/ha and Mazid et al. (1997) recorded a gross production of $3600 \mathrm{~kg} / \mathrm{ha}$. Again, Sumitra et al., (1981) who reported a significant increase in fish growth due to the effect of nutrients on the planktonic productivity of a commercial pond. Munir et al. (2016) reported dietary prebiotics and probiotics influence the growth performance of snakehead (Channa striata) fingerlings.

Azim et al. (2002) and Islam et al. (2008) also concluded that artificial diet comprising of rice bran, soybean meal, fish meal, vegetable oil, vitamin and mineral mixture (40:20:10:3:2) influenced the growth and survival of carp fingerlings on the basis of specific growth rate and harvested fish biomass. Agarwal et al. (1980) Studied on survival, growth and morphological changes of Cirrhina mrigala are reported under ascorbic acid. Similar results as present study were previously suggested by of Mehrim (2001) and Diab et al. (2002) for tilapia. Later, Khattab et al. (2004) and Mohamed et al. (2007) who also indicated that the Nile tilapia (Oreochromis niloticus) fingerlings fed on diets supplemented by prebiotics exhibited better growth than those fed with the control diet. Additionally, Misra et al. (2007) conducted to evaluate the efficacy of dietary L-ascorbic acid (AA) dosages on immunity, growth of the fingerlings of L. rohita. They indicated that elevated levels of dietary AA could be recommended for optimum immunity, growth of fingerlings of L. rohita. Furthermore, Hussein et al. (2016) studied was carried out to compare the effect of some commercial growth promoters on growth performance, feed utilization, body composition and blood pictures of juveniles common carp reared in earthen ponds. These results suggested that supplementing diets with commercial feed additives promotes growth performance, feed utilization and net financial return comparing with the control. Though, no work had been found to see combine effect of vitamins, minerals, amino acids and prebiotics on fish species, above researchers' findings supported the recent findings.

It is possible to conclude that the nutrients enriched feed premix significantly $(\mathrm{P}<0.05)$ improved growth and total production with improved feed efficiency. In this study, treatment with nutrients enriched feed premix showed highest weight gain compare with others this might be attribute to the fact that, feed premix contains different vitamins, minerals, amino acids and prebiotics that promotes growth. The results of the present study also showed that average gain in body weight of all the fish species together was less in the treatment without feed premix than that in the treatment with feed premix. The net fish production in T-2 was found to be 3607.33 
$\mathrm{kg} / \mathrm{ha}$; while in $\mathrm{T}-1$ it was $2238.06 \mathrm{~kg} / \mathrm{ha}$. Indeed, there was 0.60 times greater net fish production in $\mathrm{T}-2$ than that in T-1.

In the present study, the enhanced production in T-2 can be justified by the fact that the nutrients enriched feed premix not only contributed to fish growth but also helpful for the pond environment. This research would be useful for the aquaculture production enhancement in Bangladesh as well as other Asian countries.

\section{Conclusions}

Rohu (L. rohita), catla (C. catla) and mrigal (C. mrigala) species which have a high market value and a simple culture technique. Yet, a very few research has been commenced to enhance the growth and production performance of these species. Nutrients enriched feed premix could be very effective for the cultivation of these species as they enhance the growth and production. This study clearly showed that feed premix effect on fish growth. These feed premix are very much beneficial for fish production. Suitable production was found in T-2 than T-1 which had no premix. So, this investigation revealed that application of nutrients enriched feed premix contributes to higher production for all three species and generate better economic returns.

\section{Conflict of interest}

None to declare.

\section{References}

Ahmed H, 2004. Promotion of small indigenous fish species (SIS)-mola based carp polyculture technology at Gazipur area of Bangladesh. M.S. dissertation, Dept. of Fisheries Management, Bangladesh Agricultural University, Mymensingh. pp. 85.

Asaduzzaman M, 2005. The potentials of organic farming of giant freshwater prawn (Macrobrachium rosenbergii) in Bangladesh. M.S. dissertation, Dept. of Fisheries Management, Bangladesh Agricultural University, Mymensingh. pp. 125.

Azim ME, A Milstein, MA Wahab and MCJ Verdegam, 2003. Periphyton-water quality relationships in fertilized fishponds with artificial substrates. Aquaculture, 228: 169-187.

Azim ME, MCJ Verdegem, MM Rahman, MA Wahab, AA Van Dam and MCM Beveridge, 2002. Evaluation of polyculture of Indian major carps in periphyton-based ponds. Aquaculture, 213: 131-149.

De Silva SS and MR Hasan, 2007. Feeds and fertilizers: the key to long-term sustainability of Asian aquaculture. FAO Fisheries Technical Paper, 497, 19.

Dhur A, P Galan and S Hercberg, 1991. Vitamin A deficiency and immunity. J. Clin. Biochem. Nutr., 11: 1-19.

Diab AS, OG EL-Nagar and MY Abd-El-Hady, 2002. Evaluation of Nigella sativa L. (black seeds; baraka), Allium sativum (garlic) and Biogen as a feed additives on growth performance of Oreochromis niloticus fingerlings. Vet. Med. J., Suez Canal University, V2: 745-753.

DoF (Department of Fisheries), 2012. Sharonika, Madsha Saptha-2012. Department of Fisheries, Ministry of Fisheries and Livestock, Government of Peoples Republic of Bangladesh, 135.

FAO, 1997. FAO Fisheries Circular, 886: 163 pp.

Halver JE, 2002. The vitamins. In Halver JE and Hardy RW (eds) Fish Nutrition, 3rd edn. Academic Press, San Diego, California, pp. 61-141.

Hamre K, 2011. Metabolism, interaction, requirements and functions of vitamin E in fish. Aquacult. Nutr., 17: 98-115.

Hosen MA, Shahjahan M, Rahman MS and Alam MJ, 2014. Effects of artificial feeds on growth and production of fishes in polyculture. Int. J. Agril. Res. Innov. \& Tech., 4: 11-15.

Hossain MAR, MZ Ali, MNA Khanam, S Devnath and AKM Amin, 2002. Participatory rural appraisal with small indigenous species of fish retailers in two fish markets. Progress. Agric., 13: 133-138.

Huq KA, SMI Manir, MM Rahman and KS Ferdous, 2004. Production performance of Macrobrachium rosenbergii (De Man) in monoculture versus polyculture system. Journal of Bangladesh Agriculture University, 2: 141-149.

Hussein MS, A Zaghlol, NFAE Hakim, ME Nawsany and HA Abo-State, 2016. Effect of different growth promoters on growth performance, feed utilization and body composition of common carp (Cyprinus carpio). Journal of Fisheries and Aquatic Science, 11: 370-377.

Islam MS, KA Huq and MA Rahman, 2008. Polyculture of Thai pangus (Pangasius hypophthalmus, Sauvage 1878) with carp and prawn: a new approach in polyculture technology regarding growth performance and economic returns. Aquacult. Res., 39: 1620-1627.

Jurin M and IF Tannock, 1972. Influence of vitamin A on immunological response. Immunology, 23: 283-287. 
Kanak MK, S Dewan and M Salimullah, 1999. Performance of exotic fishes with Indian major carps in polyculture under three different species combinations. Bangladesh Journal of Fisheries Research, 22: 1-6.

Khattab YAE, AME Shalaby, M Sharaf Saffa, H El-Marakby and EH RizlAlla, 2004. The physiological changes and growth performance of the Nile Tilapia Oreochromis niloticus after feeding with Biogen ${ }^{\circledR}$ as growth promoter. Egypt. J. Aquat. Biol. And Fish., 8: 145-158.

Mazid MA, M Zaher, NN Begum, MZ Ali and F Nahar, 1997. Formulation of cost effective feeds from locally available ingredients for carp polyculture systems for increased production. Aquaculture, 151: 71-78.

Mehrim AIM, 2001. Effect of some chemical pollutants on growth performance, feed and nutrient utilization of Nile Tilapia (Oreochromis niloticus). Unpublished Thesis (MSc), Saba, Basha, Alexandria University.

Misra CK, BK Das, SC Mukherjee and J Pradhan, 2007. Effects of dietary vitamin C on immunity, growth and survival of Indian major carp Labeo rohita, fingerlings. Aquacult. Nutr., 13: 35-44.

Mohamed KA, 2007. Effect of using probiotic and yeast as growth promoters in commercial diet of tilapia (Oreochromis niloticus) fingerlings. Agricultural Research Journal, Suez Canal University, 7: 41-47.

Munir MB, R Hashim, MSA Manaf and SAM Nor, 2016. Dietary prebiotics and probiotics influence the growth performance, feed utilisation, and body indices of snakehead (Channa striata) fingerlings. Trop. Life Sci. Res., 27: 111-125.

National Research Council, 1993. Nutrient Requirement of Fish. National Academy Press, Washington, DC, p. 114.

National Research Council, 2011. Nutrient Requirements of Fish and Shrimp. National Academy Press, Washington, DC.

Panush RS and JC Delafuente, 1985. Vitamins and Immunocompetence1. In World Nutritional Determinants (Vol. 45, pp. 97-132). Karger Publishers.

Rahman MM, MCJ Verdegem, LAJ Nagelkerke, MA Wahab, A Milstein and JAJ Verreth, 2006. Growth, production and food preference of rohu Labeo rohita (H.) in monoculture and in polyculture with common carp Cyprinus carpio (L.) under fed and non-fed ponds. Aquaculture, 257: 359-372.

Shahabuddin M, Miah MS and Alam MS, 1994. Study of production optimization through polyculture of indigenous and exotic carp. Bangladesh Journal of Training and Development, 7: 67-72.

Sumitra V, Kumari KL, Gropinth VJ and Bhawam RM, 1981. Aquaculture of pearl spot (Elroplus auratenis) in an Estonian pond, environmental characters, primary production, growth benefit ratio. Indian J. Marine Sci., 10: 82-87.

Uddin MS, MS Miah and MS Alam, 1994. Study on production optimization through polyculture of indigenous and exotic carps. Bangladesh J. Train. and Dev., 7: 67-72.

West CE, JHWM Rombout, AJ Van der Zijpp and SR Sijtsma, 1991. Vitamin A and immune function. Proc. Nutr. Soc., 50: 251-262. 